\title{
Lichen planus as a Side Effect of HBV Vaccination
}

\author{
A. Rebora F. Rongioletti F. Drago A. Parodi \\ Department of Dermatology, University of Genoa, Italy
}

Ferrando et al. [1] in this tissue of Dermatology report a further case of lichen planus (LP) occurring after vaccination against hepatitis B virus (HBV). We are aware of 18 cases [2-11], including 2 observed by us and still unpublished (table 1). What could have been a coincidence in 1990 [2], should be now recognized as a genuine side effect of the HBV vaccine [12].

These observations deserve some comment.

(1) Because of the diffusion of HBV vaccination, 18 cases in 7 years indicate that postvaccine LP is a rare event. Many cases may certainly go undetected or be dumped as 'skin rashes', but their theoretical importance may be underrated as well.

(2) All cases have been described in Italy and in France. It is surprising that, given the number of HBV vaccinations worldwide, similar cases have not been reported elsewhere, particularly in the USA, where a good proportion of people are of Mediterranean stock.

(3) Although a case-control study is needed to definitely exclude coincidence, we may assume that it is unlikely. The observation of 3 cases in children [9], in whom LP is extremely rare, the exacerbation after the 2nd dose [7] or after the booster dose in one of our unpublished cases, and the severity of the lesions in a patient previously infected by HBV [11], all support the causal role of vaccination.

(4) A chronic graft-versus-host(GVHR)-like autoimmune reaction has been suggested as a pathogenetic mechanism. Except for Lefort et al. [8] and Ferrando et al. [1] cases, in which LP developed as early as 7 and 15 days respectively after the 1 st dose, latency is in keeping with this interpretation. In chronic GVHR, the lichenoid eruption may develop up to months or even years after bone marrow transplantation.

(5) Whenever studied, seroconversion followed vaccination in all cases except in Ferrando et al. [1]. In the original case [2], the HBsAb titer was low (16 IU/l) and even disappeared 1 year later. In the other cases, the titers ranged between 82 [8] and 582 IU/1 [7]. In 2 cases [2 and one of our cases], also $\mathrm{HBcAb}$ was present, an antibody that cannot be induced by the vaccines. Because of the negative prevaccination serology, this was probably a false-positive finding. The absence of $\mathrm{HBeAb}$ makes very unlikely that the patient got infected in the interval between doses. An old infection was suggested when the eruption started after the 1st dose [7]. This would be the case only if the patient, infected before vaccination, did not seroconvert.

(6) The vaccines are disparate. In 2 cases, the vaccines were obtained by inactivation of a plasma-derived HBsAg, while in the other cases they were recombinant proteins. All these vaccines share only protein $\mathrm{S}$ as a common component.

HBsAg is a mosaic of epitopes ( $\mathrm{S}$, pre-S1 and pre-S2) each of which is immunogenic. While the plasma-derived vaccines contain all the epitopes, recombinant ones do not. In Pusel's [4] and Aubin's [5] cases, the vaccine did not contain the pre-S1 epitope. Recombivax [3] did not contain the pre-S2 epitope and Engerix B [7, 9, 10 and one of our upublished cases] neither pre-S1 nor pre-S2, but only S. LP, therefore, may well develop as an immune reaction to keratinocytes expressing $\mathrm{S}$ epitope. Likewise, in patients with chronic postviral hepatitis, LP would be a cytotoxic reaction to keratinocytes expressing HBs and not epitopes shared by the hepatocytes damaged by the virus as suggested [13].

More simply, the vaccine may stimulate the immune system nonspecifically triggering LP eruption as it does with other immune-related disorders, including lupus erythematosus [14]. However, we are unaware of lichenoid eruption

\footnotetext{
Dr. Alfredo Rebora

Department of Dermatology, University of Genoa

Viale Benedetto XV

I-16132 Genova (Italy)

Tel. +3910353 8414, Fax +39103538401
}

E-Mail kargr@kargerch

1018-8665/99/1981-0001\$17.50/0

www.karger.com

http://BioMedNet.com/karger 
Table 1. Cases of LP following HBV vaccination

\begin{tabular}{|c|c|c|c|c|c|}
\hline Authors & Age, sex & $\begin{array}{l}\text { Approximate latency } \\
\text { after late dose, days }\end{array}$ & Vaccine & Epitopes & Seroconversion, IU/1 \\
\hline Ciaccio and Rebora, 1990 & $30, \mathrm{f}$ & $20(3 \mathrm{rd})$ & Hevac $B^{1}$ & $\mathrm{~S}$, pre-S1, pre-S2 & 16 \\
\hline Trevisan and Stinco, 1993 & $19, \mathrm{f}$ & 60 (2nd) & Recombivax $^{2}$ & $\mathrm{~S}$, pre-S1 & + \\
\hline Pusel et al., 1993 & $25, \mathrm{f}$ & 30 (2nd) & Gen Hevac B ${ }^{2}$ & $\mathrm{~S}$, pre-S2 & 300 \\
\hline Aubin et al., 1994 & $50, \mathrm{~m}$ & 30 (2nd) & Gen Hevac B & $\mathrm{S}$, pre-S2 & + \\
\hline \multirow[t]{2}{*}{ Grezard et al., 1995} & $57, \mathrm{f}$ & $60(3 \mathrm{rd})$ & Gen Hevac B & $\mathrm{S}$, pre-S2 & ND \\
\hline & $43, \mathrm{~m}$ & $60(3 \mathrm{rd})$ & Gen Hevac B & $\mathrm{S}$, pre-S2 & 118 \\
\hline Leport, 1995 & $27, \mathrm{f}$ & $12(2 \mathrm{nd})$ & Engerix $\mathrm{B}^{2}$ & S & 582 \\
\hline Lefort et al., 1995 & $15, \mathrm{f}$ & $7(1 \mathrm{st})$ & Gen Hevac B ${ }^{2}$ & $\mathrm{~S}$, pre-S2 & 82 \\
\hline \multirow[t]{3}{*}{ Moraillon et al., 1996} & $7, \mathrm{f}$ & $\approx 30$ (2nd?) & Gen Hevac ${ }^{2}$ & $\mathrm{~S}$, pre-S2 & + \\
\hline & $3, \mathrm{~m}$ & $\approx 30$ (2nd?) & Gen Hevac ${ }^{2}$ & $\mathrm{~S}$, pre-S2 & + \\
\hline & $5, \mathrm{~m}$ & same (2nd) & Engerix $\mathrm{B}^{2}$ & $\mathrm{~S}$ & + \\
\hline \multirow[t]{3}{*}{ Gisserot et al., 1997} & $35, \mathrm{f}$ & $30(3 r d)$ & Engerix $\mathrm{B}^{2}$ & $\mathrm{~S}$ & $?$ \\
\hline & $50, \mathrm{~m}$ & 15 (3rd) & Gen Hevac B ${ }^{2}$ & $\mathrm{~S}$, pre-S2 & $?$ \\
\hline & $19, \mathrm{~m}$ & 45 (2nd) & Engerix $\mathrm{B}^{2}$ & $\mathrm{~S}$ & $?$ \\
\hline Saywell et al., 1997 & $16, \mathrm{~m}$ & 35 (2nd) & $?$ & $?$ & $?$ \\
\hline Ferrando et al., 1997 & $33, \mathrm{~F}$ & $15(1 \mathrm{st})$ & Gen Hevac B ${ }^{2}$ & $\mathrm{~S}$, pre-S2 & ND \\
\hline \multirow[t]{2}{*}{ Our cases } & $39, \mathrm{~m}$ & $120(2 \mathrm{nd})$ & H-B-VAX ${ }^{1}$ & $\mathrm{~S}$, pre-S1, pre-S2 & + \\
\hline & $54, \mathrm{f}$ & $120(3 \mathrm{rd})$ & Engerix $\mathrm{B}^{2}$ & $\mathrm{~S}$ & 350 \\
\hline
\end{tabular}

$\mathrm{ND}=$ Not done. ${ }^{1}$ Plasma derived.${ }^{2}$ Recombinant.

following vaccines other than HBV. In addition, the severity of the manifestations in the patient who had had a previous contact with HBV [11], suggests a direct relationship with the infection.

(7) The unsuccessful attempt to identify HBs epitopes in the keratinocytes [4] using polyclonal antibodies may have dependend on the inadequacy of the method used.

(8) Patients showing LP eruption before completing the vaccination should not receive further injections [15]. Those who have been supposedly in contact with the virus should not be vaccinated as they are more likely to develop severe LP lesions.

Now that 'the clinical association between LP and liver diseases is well recognized' even outside the mediterranean countries [16], it would be a pity if the 'HCV fashion' obscured the role of HBV and, with it, the notion that LP is probably a stereotypical cell-mediated reaction to antigens of a most heterogeneous nature.

\section{References}

1 Ferrando MF, Doutre MS, Beylot-Barry M, Beylot C, Durand I: Lichen planus following hepatitis B vaccination. Submitted.

2 Ciaccio M, Rebora A: Lichen planus following HBV vaccination: A coincidence? Br J Dermatol 1990;122: 424

3 Trevisan G, Stinco G: Lichen planus following HBV vaccination. Acta Dermatol Venereol 1993;73:73

4 Pusel B, Will F, Grosshans E: Lichen plan et vaccination contre 1'hépatite B. Nouv Dermatol 1993;12:709-710.

5 Aubin F, Angonin R, Humbert Ph, Agache P: Lichen planus following HBV vaccination. Arch Dermatol 1994;130:1329-1330.

6 Grézard P, Philippot V, Perrot H: Lichen plan et vaccination contre l'hépatite $B$. Deux observations. Nouv Dermatol 1995;14:444-445.
7 Leport Y: Lichen plan et vaccin contre l'hépatite B. Nouv Dermatol 1995;14:594.

8 Lefort A, Dachary D, Vergier B, Boiron G: Lichen plan et vaccination anti-hépatite B. Ann Dermatol Vénéréol 1995;122:701-703.

9 Moraillon I, Merle F, Laglenne S, Vignon MD, Prigent F, Bourrilon A, et al: Lichen plan de l'enfant après vaccination anti-hépatite $B$. 3 cas. Ann Dermatol Vénéréol 1996;123:s63.

10 Gisserot O, Carsuzaa F, Marleir S, Morand JJ, Marrot E: Lichen planus after hepatitis B vaccination. 3 new cases. Presse Méd 1997;26:760.

11 Saywell CA, Wittal RA, Kossard S: Lichenoid reaction to hepatitis B vaccination. Australas J Dermatol 1997;38:152-154.

12 Martindale: The Extra Pharmacopoeia. London, The Pharmaceutical Press, 1993, p 1283.
13 Rebora A: Lichen planus and the liver. Int J Dermatol 1992;31:392-395.

14 Grézard P, Chefaï M, Philippot V, Perrot H, Faisant M: Lupus érythémateux cutané et aphtose buccale après vaccination contre l'hépatite B chez un enfant âgé de 6 ans. Ann Dermatol Vénéréol 1996;123:657-659.

15 PDR Generics: Medical Economics. Montvale, 1995, p 1391.

16 Imhof M, Popal H, Lee J-H, Zeuzem S, Milbradt $\mathrm{R}$ : Prevalence of hepatitis $\mathrm{C}$ virus antibodies and evaluation of hepatitis $\mathrm{C}$ virus genotypes in patients with lichen planus. Dermatology 1997;195:1-5. 